Zeszyty Naukowe Szkoły Głównej Gospodarstwa Wiejskiego w Warszawie Problemy Rolnictwa Światowego tom 17 (XXXII), zeszyt 3, 2017: 226-238

DOI: 10.22630/PRS.2017.17.3.69

Karol Kukuła ${ }^{1}$

Uniwersytet Rolniczy w Krakowie

\title{
Zanieczyszczenia środowiska a działalność proekologiczna w Polsce w 2015 roku w świetle wielowymiarowej analizy porównawczej
}

\section{Environmental Pollution and Pro-ecological Activity in Poland in 2015 in the Aspect of Multidimensional Comparative Analysis}

\begin{abstract}
Synopsis. Rozwój cywilizacyjny niesie z sobą postępujący proces degradacji środowiska. Aby zapobiec ewentualnie ograniczyć skutki tego procesu, podejmuje się działania proekologiczne. Celem artykułu jest ukazanie kształtowania się tych dwóch zjawisk w ujęciu regionalnym w Polsce. Obydwa zjawiska należą do kategorii złożonych, stąd w ich badaniu stosuje się narzędzia wielowymiarowej analizy porównawczej. Wzięto pod uwagę jeszcze jedno zjawisko (proste) tj. wielkość ponoszonych nakładów na środki trwałe służące środowisku. Zbudowano trzy rankingi województw ze względu na wymienione zjawiska:

- stopień zanieczyszczenia środowiska,

- wielkość nakładów na środki trwałe, służących środowisku,

- poziom działalności proekologicznej.

Otrzymane rankingi oraz porównania międzyrankingowe pozwalają sformułować wniosek, iż działania proekologiczne realizowane w Polsce nie nadążają za zanieczyszczeniami środowiska.
\end{abstract}

Słowa kluczowe: zanieczyszczenie, ochrona środowiska, działalność proekologiczna, ranking, porównanie

\begin{abstract}
The development of civilization is attached with the progressive degradation of the environment. In order to prevent the after-effects of this process pro-ecological activities are undertaken. The aim of this paper is to show the interactions between the two phenomena in the regional aspect in Poland. Both of these phenomena can be classified as complex, therefore the investigation is based on the application of the tools of multidimensional comparative analysis. Another (simple) phenomenon was also taken into account, i.e. the level of expenditures on capital assets connected with environmental protection. Three ranking arrangements of voivodships have been constructed with respect to the phenomena mentioned before:

- the degree of environmental pollution,

- the size of expenditures on capital assets connected with environmental protection,

- the level of pro-ecological activity.

The ranking arrangements obtained and their comparisons allow for the formulation of the conclusion that the pro-ecological activities that are carried out in Poland are far behind the pollution of the environment.
\end{abstract}

Key words: pollution, environment, pro-ecological activity, ranking, comparison

${ }^{1}$ prof. zw. dr hab., Katedra Statystyki i Ekonometrii, Wydział Rolniczo-Ekonomiczny, UR w Krakowie, al. Mickiewicza 21,31-120 Kraków e-mail: ksm@ur.krakow.pl 


\section{Wprowadzenie}

Rozwój gospodarczy niesie z sobą wiele pozytywów ale wywołuje także pewne ujemne skutki. Wiele $\mathrm{z}$ tych zjawisk negatywnie postrzeganych występuje na świecie ale daje się również zauważyć w Polsce, stając się źródłem trudnych do rozwiązania problemów (Poskrobko, 1987; Dobrzański i in., 2009). Wymienię tylko kilka dziedzin, w których owe ujemne zjawiska występują. W pierwszej kolejności wymienić należy energetykę opartą na węglu, emitującą olbrzymie masy gazów zaliczanych do cieplarnianych. Kolejno transport, wytwarzający coraz to większe ilości szkodliwych dla środowiska substancji gazowych. Rolnictwo odprowadzające do gleb potężne ilości ścieków zatruwających środowisko. Należy wreszcie wspomnieć o odpadach powstających w przemyśle ale również w gospodarstwach domowych - odpady komunalne. Odpady te często są gromadzone na wysypiskach pozbawionych urządzeń do ich konwersji. Wszystko to skłania do podjęcia odpowiednich działań ograniczających bądź eliminujących owe niekorzystne dla środowiska czynniki. Aktywności te występują pod nazwą działalności proekologicznej.

Działalność proekologiczna wiąże się z podejmowaniem odpowiednich inwestycji

oraz posunięć organizacyjnych $w$ regionach szczególnie narażonych na pogłębiające się procesy degradacji środowiska. Jedną $\mathrm{z}$ nich jest ponoszenie nakładów na środki trwałe służące ochronie środowiska.

Celem artykułu jest regionalna analiza stanu skażenia środowiska $\mathrm{w}$ zderzeniu z oceną poziomu realizowanych działań proekologicznych. Jeśli przyjąć tezę, że regiony najbardziej zanieczyszczające środowisko powinny w podobnym stopniu podejmować działalność proekologiczną to istotnym pytaniem jakie się nasuwa jest kwestia, jak ta sytuacja kształtuje się w Polsce w poszczególnych województwach? Na pytanie to, choćby tylko częściowo, starano się znaleźć odpowiedź poprzez zastosowanie porównań międzyrankingowych. Należy zauważyć, że zarówno poziom skażenia środowiska jak i działalność proekologiczna są zjawiskami złożonymi opisywanymi jednocześnie przez więcej niż jedną zmienną (Kukuła, 2000). Do zjawisk tych dołączono jedno zjawisko zaliczane do prostych opisywanych przez jedną zmienną (Jajuga, 1993) a mianowicie wysokość nakładów na środki trwałe służące środowisku przeliczone na $1 \mathrm{~km}^{2}$. Łatwo zauważyć, że wielkość nakładów na środki trwałe pozostaje $\mathrm{w}$ określonym związku ze stopniem skażenia środowiska oraz $\mathrm{z}$ poziomem działań proekologicznych. W ramach każdego z trzech wymienionych zjawisk zbudowano ranking województw:

$\mathrm{R}_{1}$ - ranking obrazujący stopień skażenia środowiska w poszczególnych województwach (od największych trucicieli do najmniej szkodzących środowisku,

$\mathrm{R}_{2}$ - ranking województw ze względu na skalę nakładów skierowanych na środki trwałe służące środowisku,

$\mathrm{R}_{3}$ - ranking obiektów (województw) ukazujący intensywność działań proekologicznych realizowanych na ich obszarze.

Czystość środowiska naturalnego w Polsce przejawia pewne oznaki przestrzennego zróżnicowania (por. Kukuła, 2014). Na obecny stan rzeczy wpływają niewątpliwie takie zjawiska jak, nierówno przestrzennie rozłożone uprzemysłowienie kraju a także poziom urbanizacji poszczególnych województw. Również podejmowane w przeszłości działania proekologiczne lub zaniechania tych działań mogły ukształtować obecny obraz zjawiska określanego stanem środowiska. 


\section{Proponowane metody}

Analiza regionalna obejmuje $\mathrm{n}$ obiektów $(i=1, \ldots, n)$, z których każdy jest opisywany przez $\mathrm{m}$ zmiennych zwanych diagnostycznymi $(j=1, \ldots, m)$. Zatem bazę danych tworzy macierz:

$$
\left[x_{i j}\right]=\left[\begin{array}{cccc}
x_{1} & x_{12} & \ldots & x_{1 m} \\
x_{2} & x_{22} & \ldots & x_{2 m} \\
\ldots & \ldots & \ldots & \ldots \\
x_{n 1} & x_{n 2} & \ldots & x_{n m}
\end{array}\right]
$$

Korzystając $\mathrm{z}$ danych zawartych $\mathrm{w}$ macierzy (1) zastosowano dwie metody porządkowania liniowego (Kukuła, Luty, 2015): metodę unitaryzacji zerowanej (w budowie rankingu $R_{3}$ ) oraz metodę rangową przy tworzeniu rankingu $R_{1}$. Ranking $R_{2}$ został skonstruowany na bazie jednej zmiennej (nakłady na środki trwałe służące środowisku, przypadające na $1 \mathrm{~km}^{2}$ ). Przejdźmy dalej do opisu stosowanych w badaniu metod.

\section{Metoda podziału obiektów na grupy}

Przedmiotem badania jest ranking złożony z $n$ obiektów, uporządkowanych nierosnąco względem zmiennej syntetycznej $\mathbf{Q}$. Należy dokonać ich podziału na $k$ grup: $G_{1}, G_{2}, \ldots, G_{k}$. Numer grupy oznaczono symbolem $l$, gdzie $l=1, \ldots, k$ oraz $k \leq n$. W pierwszej kolejności należy wyznaczyć rozstęp zmiennej syntetycznej:

$$
R\left(Q_{i}\right)=\max _{i} Q_{i}-\min _{i} Q_{i}, \quad(\mathrm{i}=1, \ldots, \mathrm{n})
$$

Zakładając, że rozkład empiryczny zmiennej syntetycznej Q jest rozkładem prostokątnym, proponuje się podział wszystkich obiektów tworzących ranking na $k$ (dowolna liczba nie większa niż $n$ ) grup w sposób następujący:

$$
G_{l} \text { dla } Q_{i} \in\left[\min Q_{i}+\frac{k-l}{k} R\left(Q_{i_{i}}\right), \min Q_{i}+\frac{k-l+1}{k} R\left(Q_{i}\right)\right) \text {. }
$$

Pierwszą grupę $G_{l}$ charakteryzuje przedział wartości zmiennej syntetycznej zawsze obustronnie domknięty. 


\section{Metoda porównań międzyrankingowych}

Badania porównawcze między rankingami stwarzają konieczność określenia stopnia ich podobieństwa. Porównanie w sposób kwantytatywny dwóch rankingów $R_{p} i R_{q}-($ Kukuła, 1986): umożliwia skorzystanie z miary podobieństwa $m_{p q}$ :

$$
m_{p q}=1-\frac{2 \sum_{i=1}^{n}\left|c_{i p}-c_{i q}\right|}{n^{2}-z},\left(\begin{array}{c}
i=1, \ldots, n \\
p, q=1, \ldots, h
\end{array}\right)
$$

$c_{i p}$ - pozycja $i$ - tego obiektu (województwa) w rankingu o numerze $p$,

$c_{i q}$ - pozycja $i$ - tego obiektu (województwa) w rankingu o numerze $q$, przy czym:

$$
z=\left\{\begin{array}{lll}
0 & g d y & n \in N_{p} \\
1 & g d y & n \notin N_{p}
\end{array}\right.
$$

gdzie $\mathrm{N}_{\mathrm{p}}$ - zbiór liczb naturalnych parzystych.

Dana wzorem (4) miara przyjmuje wartości z przedziału:

$$
m_{p q} \in[0,1]
$$

Jeśli porównywane rankingi $R_{p}$ oraz $R_{q}$ są identyczne, wówczas $m_{p q}=1$, jeśli zaś porównywane rankingi diametralnie się różnią, wówczas $m_{p q}=0$. Tak wyznaczone wartości $m_{p q}$ tworzą macierz $M$ :

$$
M=\left[m_{p q}\right]=\left[\begin{array}{cccc}
1 & m_{12} & \ldots & m_{1 h} \\
m_{21} & 1 & \ldots & m_{2 h} \\
& & & \\
m_{h 1} & m_{h 2} & \ldots & 1
\end{array}\right]_{(h x h)}
$$

Macierz (7) jest macierzą kwadratową o wymiarach (hxh) a ponadto jest macierzą symetryczną, ponieważ:

$$
\begin{array}{ll} 
& m_{p q}=m_{q p} \text { dla } p \neq q \\
\text { oraz } \quad \mathrm{m}_{\mathrm{pq}}=1 & \text { dla } p=q .
\end{array}
$$

Dane zawarte w macierzy $M$ umożliwiają przeprowadzenie porównań międzyrankingowych w zakresie ich podobieństwa. 


\section{K. Kukuła}

\section{Ranking województw ze względu na stopień zanieczyszczenia środowiska}

Sprecyzowanie stopnia skażenia środowiska w poszczególnych województwach bazuje na kilku wybranych zmiennych zwanych zmiennymi diagnostycznymi. Poziom skażenia środowiska potraktowano jako zjawisko złożone możliwe do opisania przez kilka zmiennych (Kukuła, 2000). Do budowy rankingu województw wg stopnia zanieczyszczenia środowiska wybrano 7 cech diagnostycznych. Są to:

$\mathrm{X}_{1}$ - emisja zanieczyszczeń pyłowych z zakładów szczególnie uciążliwych dla środowiska $\mathrm{wt} / 100 \mathrm{~km}^{2}$,

$\mathrm{X}_{2}$ - emisja zanieczyszczeń gazowych z zakładów szczególnie uciążliwych dla środowiska $\mathrm{w} \mathrm{t} / 100 \mathrm{~km}^{2}$,

$\mathrm{X}_{3}$ - nieczyszczone ścieki przemysłowe i komunalne odprowadzone do wód i do ziemi $\mathrm{w} \mathrm{m} / 100 \mathrm{~km}^{2}$,

$\mathrm{X}_{4}$ - udział powierzchni gruntów zdewastowanych i zdegradowanych (wymagających rekultywacji w ogólnej powierzchni województwa w \%o,

$\mathrm{X}_{5}$ - powierzchnia dzikich wysypisk $\mathrm{w} \mathrm{m}^{2} / 100 \mathrm{~km}^{2}$,

$\mathrm{X}_{6}$ - emisja ołowiu z zakładów szczególnie uciążliwych dla środowiska $\mathrm{w} \mathrm{g} / 100 \mathrm{~km}^{2}$,

$\mathrm{X}_{7}$ - emisja rtęci z zakładów szczególnie uciążliwych dla środowiska $\mathrm{w} g / 100 \mathrm{~km}^{2}$.

Wszystkie te zmienne są stymulantami ze względu na stopień zanieczyszczenia środowiska. Stąd zrangowano poszczególne zmienne, zaś ich suma stanowi wartość zmiennej syntetycznej i określa poziom zanieczyszczeń w danym województwie. $\mathrm{Na}$ podstawie wartości zmiennej agregatowej (syntetycznej) zbudowano ranking województw zaprezentowany w tabeli 1 .

Tabela 1. Ranking województw ze względu na stopień zanieczyszczenia środowiska w 2015 roku

Table 1. Ranking arrangement of voivodships with respect to the level of environmental pollution in 2015

\begin{tabular}{c|lcc}
\hline Lp. & \multicolumn{1}{|c}{ Województwo } & Wartość zmiennej syntetycznej Q & Grupa \\
\hline 1 & ślaskie & 12 & I \\
2 & dolnoślaskie & 25 & (4 województwa) \\
3 & opolskie & 33 & \\
4 & świetokrzyskie & 33 & II \\
\hline 5 & lódzkie & 45 & (6 województw) \\
6 & małopolskie & 51 & \\
7 & wielkopolskie & 52 & \\
8 & kujawsko-pomorskie & 56 & III \\
9 & mazowieckie & 60 & (6 województw) \\
10 & zachodniopomorskie & 71 & \\
11 & lubelskie & 78 & \\
12 & pomorskie & 79 & \\
13 & podlaskie & 80 & \\
14 & podkarpackie & 82 & 92 \\
15 & lubuskie & 103 & \\
16 & warmińsko-mazurskie & 8,583 & \\
\hline
\end{tabular}

Źródło: obliczenia własne na podstawie danych zawartych w: Ochrona Środowiska Environment 2016, GUS Warszawa. 
Stosując formułę zapisaną wzorem (3) podzielono województwa na 3 grupy:

Grupa I o wysokim stopniu, skażenia środowiska,

Grupa II o przeciętnym poziomie skażenia środowiska,

Grupa III o relatywnie niskim poziomie zanieczyszczenia środowiska.

Do grupy I należą cztery województwa: śląskie, dolnośląskie, opolskie i świętokrzyskie (kolejność jak w rankingu). Trzy pierwsze województwa nie są zaskoczeniem, czego nie można powiedzieć o województwie świętokrzyskim, które zajmuje czwartą lokatę w rankingu największych trucicieli środowiska.।

Grupę II o umiarkowanym stopniu skażenia tworzy 6 województw: łódzkie, małopolskie, wielkopolskie, kujawsko-pomorskie, mazowieckie i zachodniopomorskie. Są to województwa stosunkowo dobrze uprzemysłowione, posiadające wielkie aglomeracje miejskie, ale również mające znaczące obszary wykorzystywane rolniczo.

Grupa III stanowi obszary o relatywnie niskim stopniu degradacji i środowiska. Do grupy tej należy także 6 województw, lubelskie, pomorskie, podlaskie, podkarpackie, lubuskie i warmińsko-mazurskie. Województwa te są stosunkowo mniej zurbanizowane, niżej uprzemysłowione za to bardziej nastawione na rolnictwo.

Biorąc pod uwagę prezentowany układ porządkowy (tab.1 oraz rys.1), wypada stwierdzić, iż zmienna syntetyczna Q przejawia znaczny stopień zróżnicowania $\left[I\left(Q_{i}\right)>8\right]$, zob. tab.1. Iloraz wartości skrajnych tej zmiennej ukazuje, iż województwo śląskie - o najbardziej zanieczyszczonym środowisku- przewyższa ponad ośmiokrotnie województwo warmińsko- mazurskie o relatywnie najniższym poziomie skażenia środowiska.

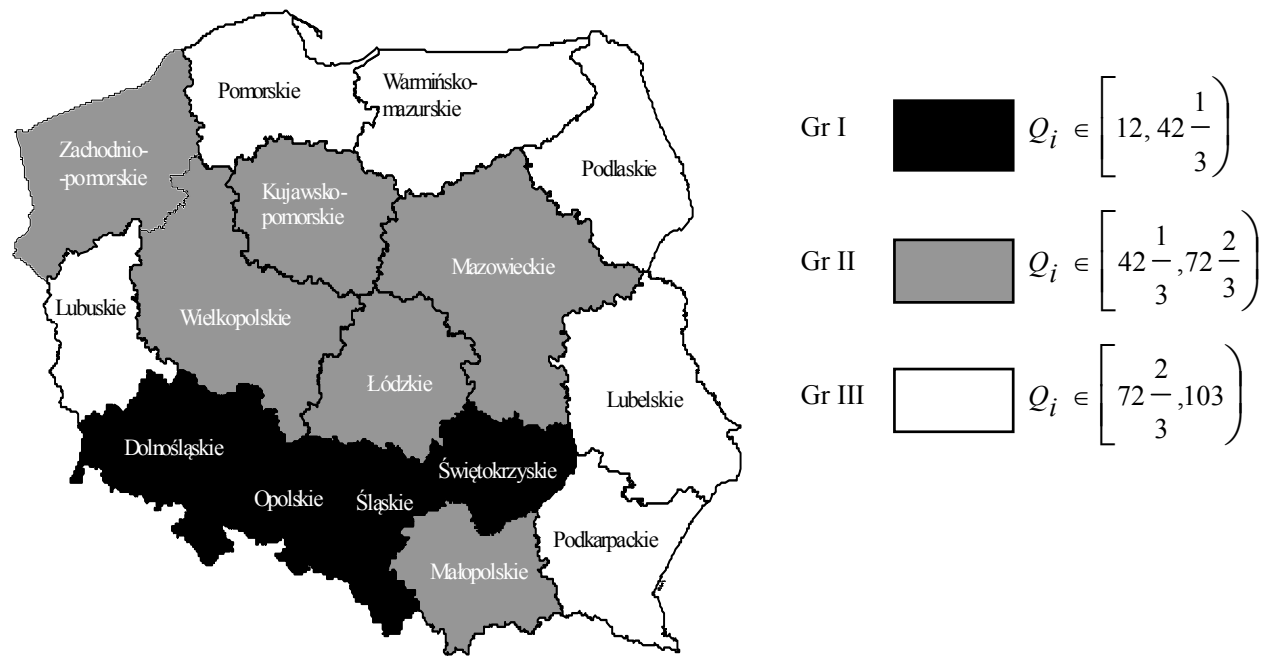

Rys. 1. Stopień zanieczyszczenia środowiska w 2015 roku w ujęciu regionalnym.

Fig. 1. Groups of voivodships: breakdown by the level of environmental protection on 31.12.2015.

Źródło: opracowanie własne na podstawie danych zawartych w tab. 1. 


\section{K. Kukuła}

\section{Ranking województw względem wielkości nakładów na środki trwałe sprzyjające ochronie środowiska w 2015 roku}

Nakłady na środki trwałe angażowane w ochronę środowiska służą poprawie jego jakości (Kukuła, 2014). Na bazie jednej zmiennej tj wartości nakładów na środki trwałe służące środowisku w 2015 roku zbudowano ranking województw (tab. 2).

Tab. 2. Ranking województw ze względu na wielkość nakładów przeznaczonych na środki trwałe służące środowisku w zł $/ \mathrm{km}^{2}$ w 2015 roku

Table 2. Ranking arrangement of voivodships with respect to the level of expenditures on capital assets in $\mathrm{zl} / \mathrm{km}^{2}$ in 2015

\begin{tabular}{c|lrc}
\hline Lp. & \multicolumn{1}{|c}{ Województwo } & $\mathbf{Q}_{\mathbf{i}}$ & Grupa \\
\hline 1 & śląskie & 162403 & I (1 obiekt) \\
\hline 2 & małopolskie & 107770 & II \\
3 & lubelskie & 79727 & (4 województwa) \\
4 & wielkopolskie & 67786 & \\
5 & mazowieckie & 62025 & \\
\hline 6 & dolnośląskie & 58689 & III \\
7 & pomorskie & 46261 & (11 województw) \\
8 & kujawsko-pomorskie & 44909 & \\
9 & lódzkie & 44581 & \\
10 & opolskie & 44057 & \\
11 & świętokrzyskie & 39809 & \\
12 & zachodniopomorskie & 30936 & \\
13 & lubuskie & 30726 & \\
14 & podkarpackie & 27777 & \\
15 & podlaskie & 18809 & \\
16 & warmińsko-mazurskie & 11534 & \\
\hline
\end{tabular}

Źródło: obliczenia własne na podstawie danych zawartych w: Ochrona Środowiska Environment 2016, GUS Warszawa. 
Na rysunku 2 przedstawiono przestrzenny rozkład tej zmiennej.

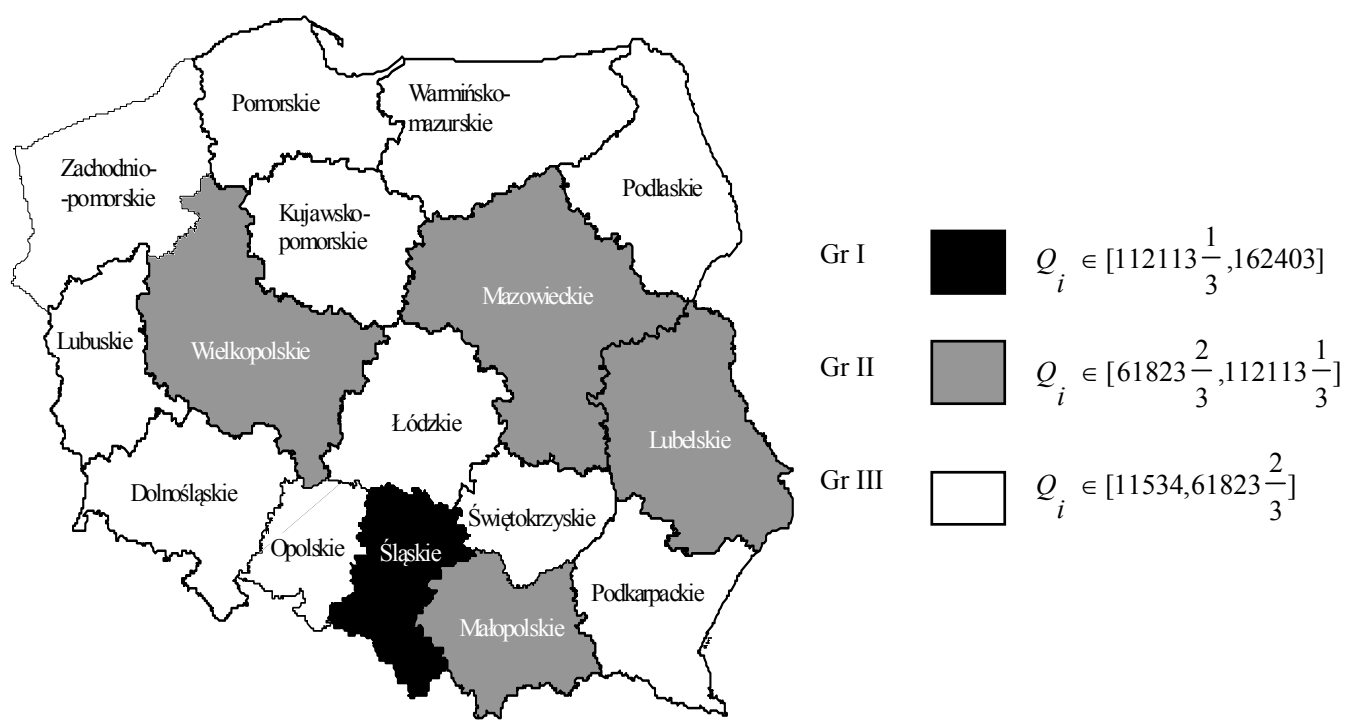

Rys. 2. Województwa podzielone na grupy względem wielkości nakładów poniesionych na środki trwałe służące ochronie środowiska w 2015 roku.

Fig. 2. Voivodships divided into groups according to the size of expenditures on capital assets for environmental protection in 2015

Źródło: opracowanie własne na podstawie danych zawartych w tab. 2.

Grupa I jest złożona z jednego obiektu. Jest nim województwo śląskie, które wysokością nakładów na omawiane środki znacznie przewyższa pozostałe regiony. Największy truciciel środowiska ponosi najwyższe nakłady na środki służące poprawie jakości środowiska. Zaszłość ta wydaje się w pełni uzasadniona.

Grupę II tworzą 4 województwa, są to: małopolskie, lubelskie, wielkopolskie $\mathrm{i}$ mazowieckie. Województwa te należą również do grupy II $\mathrm{w}$ rankingu, zanieczyszczających środowisko w sposób umiarkowany.

Do grupy III należy najwięcej województw bo aż 11. Grupa ta charakteryzuje się relatywnie niskimi nakładami na środki trwałe sprzyjające środowisku. Do grupy III należą województwa: dolnośląskie, pomorskie, kujawsko-pomorskie, łódzkie, opolskie, świętokrzyskie, zachodniopomorskie, lubuskie, podkarpackie, podlaskie i warmińsko mazurskie. Dużym zaskoczeniem jest fakt, że obiekty należące do grupy największych trucicieli środowiska tj. dolnośląskie, opolskie i świętokrzyskie znalazły się w grupie najmniej inwestujących w środki sprzyjające jego ochronie.

Podsumowując należy zauważyć, iż ponoszone nakłady na środki trwałe proekologiczne są regionalnie znacznie zróżnicowane. Świadczy o tym iloraz wartości skrajnych tej zmiennej - $I\left(Q_{i}\right) \cong 14$, zob. tab.2. Oznacza to, że województwo śląskie ponosząc najwyższe nakłady na omawiane środki przewyższa pod tym względem ponad 14-to krotnie województwo warmińsko-mazurskie, zajmujące ostatnią lokatę w rankingu. 


\section{Ranking województw ze względu na poziom działalności proekologicznej w Polsce w 2015 roku}

Działalność proekologiczna rozpatrywana w obiektach przestrzennych (województwach) należy niewątpliwie do zjawisk złożonych opisywanych kilkoma zmiennymi diagnostycznymi. Spośród wielu zmiennych potencjalnych dokonano wyboru zmiennych będących bazą przy budowie rankingu. Przy wyborze kierowano się dwoma kryteriami: wagą merytoryczną oraz dostatecznym stopniem zmienności typowanej cechy. Kierując się wspomnianymi kryteriami wybrano następujące zmienne:

$\mathrm{X}_{1}$ - udział obszarów prawnie chronionych w powierzchni województwa - (\%),

$\mathrm{X}_{2}$ - powierzchnia obszarów prawnie chronionych przypadająca na 1 mieszkańca $-\left(\mathrm{m}^{2}\right)$,

$\mathrm{X}_{3}$ - udział ścieków przemysłowych i komunalnych odprowadzanych siecią kanalizacyjną w ogólnej objętości ścieków przemysłowych i komunalnych - (\%),

$\mathrm{X}_{4}$ - udział ścieków przemysłowych i komunalnych nieczyszczonych do ścieków przemysłowych i komunalnych oczyszczonych - (\%),

$\mathrm{X}_{5}$ - nakłady na gospodarkę ściekową i ochronę wód przypadającą na 1 mieszkańca - (zł),

$\mathrm{X}_{6}$ - nakłady na gospodarkę odpadami przypadające na 1 mieszkańca (zł),

$\mathrm{X}_{7}$ - odpady selektywne zebrane przypadające na 1 mieszkańca - $(\mathrm{kg})$,

$\mathrm{X}_{8}$ - nakłady na ochronę powietrza i klimatu przypadające na $1 \mathrm{~km}^{2}-(\mathrm{zł})$,

$\mathrm{X}_{9}$ - nakłady na zmniejszenie hałasu i wibracji przypadające na $1 \mathrm{~km}^{2}-$ (zł),

$\mathrm{X}_{10}$ - nakłady na komunalne oczyszczalnie ścieków przypadające na 1 mieszkańca - (zł),

$\mathrm{X}_{11}$ - nakłady na środki trwałe służące ochronie środowiska przypadające na $1 \mathrm{~km}^{2}-(\mathrm{zl})$.

Wszystkie wymienione zmienne oprócz zmiennej $\mathrm{X}_{4}$, która jest destymulantą, należą do zbioru stymulant. Przy budowie rankingu, normując cechy diagnostyczne wykorzystano metodę unitaryzacji zerowanej.

Ranking województw ze względu na poziom działalności proekologicznej zawiera tab. 3 .

Grupę I tworzą 4 województwa: małopolskie, śląskie, lubuskie i pomorskie. Dwie pierwsze pozycje w rankingu województwa małopolskie i śląskie należą do obiektów najmocniej zanieczyszczających środowisko stąd ich aktywność w zakresie działań proekologicznych nie budzi zastrzeżeń. $Z$ kolei lubuskie i pomorskie należąc do obiektów o niskim stopniu zanieczyszczenia środowiska stanowią w pewnym sensie wynik zaskakujący. Wynik ten można tłumaczyć jedynie usilną dbałością władz tych województw o utrzymanie w czystości podległych im obiektów przestrzennych. Do grupy II zaliczono 6 obiektów, są to w kolejności województwa: mazowieckie, łódzkie, wielkopolskie, podlaskie, opolskie i kujawsko - pomorskie. Działalnością gospodarczą dominującą na obszarze tych województw jest rolnictwo i przemysł. Grupę III tworzy również 6 obiektów, są to województwa: dolnośląskie, warmińsko-mazurskie, podkarpackie, świętokrzyskie, lubelskie i zachodniopomorskie. Mało oczekiwaną jest przynależność do grupy słabo podejmujących działania proekologiczne takich województw zaklasyfikowanych do grupy największych trucicieli środowiska jak: dolnośląskie (2 lokata w rankingu) oraz świętokrzyskie (4 lokata w rankingu).

Podsumowując aktywność województw na polu działań proekologicznych można stwierdzić, że poziom tej działalności jest relatywnie słabo zróżnicowany. Wystarczy zinterpretować iloraz wartości skrajnych zmiennej syntetycznej $\mathrm{Q}$, gdzie widać, iż $\mathrm{I}\left(\mathrm{Q}_{\mathrm{i}}\right)$ minimalnie przekracza liczbę 2. Oznacza to, że województwo małopolskie, zajmujące 
pierwszą lokatę $\mathrm{w}$ rankingu przewyższa zaledwie dwukrotnie województwo zachodniopomorskie plasujące się na ostatniej pozycji w omawianym rankingu.

Przestrzenny rozkład poziomu działalności proekologicznej w Polsce przedstawia rys.3.

Tab.3. Ranking województw ze względu na poziom działalności proekologicznej w 2015 roku.

Table 3. Ranking arrangement of voivodships with respect to the level of pro-ecological activity in 2015

\begin{tabular}{c|lcc}
\hline Lokata & \multicolumn{1}{|c}{ Województwo } & Wartości zmiennej & Grupa \\
\hline 1 & małopolskie & 0,519 & \\
2 & śląskie & 0,493 & I \\
3 & lubuskie & 0,459 & (4 województwa) \\
4 & pomorskie & 0,448 & \\
\hline 5 & mazowieckie & 0,409 & II \\
6 & łódzkie & 0,403 & $(6$ województw) \\
7 & wielkopolskie & 0,392 & \\
8 & podlaskie & 0,357 & \\
9 & opolskie & 0,352 & III \\
10 & kujawsko-pomorskie & 0,350 & $(6$ województw) \\
11 & dolnośląskie & 0,339 & \\
12 & warmińsko-mazurskie & 0,334 & \\
13 & podkarpackie & 0,309 & \\
14 & świętokrzyskie & 0,300 & \\
15 & lubelskie & 0,266 & \\
16 & zachodniopomorskie & 2,004 & \\
\hline
\end{tabular}

Źródło: Kukuła K., (2017), Pro-Ecological Activity in Poland in 2015 (Regional Study), Acta Scientiarum Polonorum- Oeconomia, w druku.

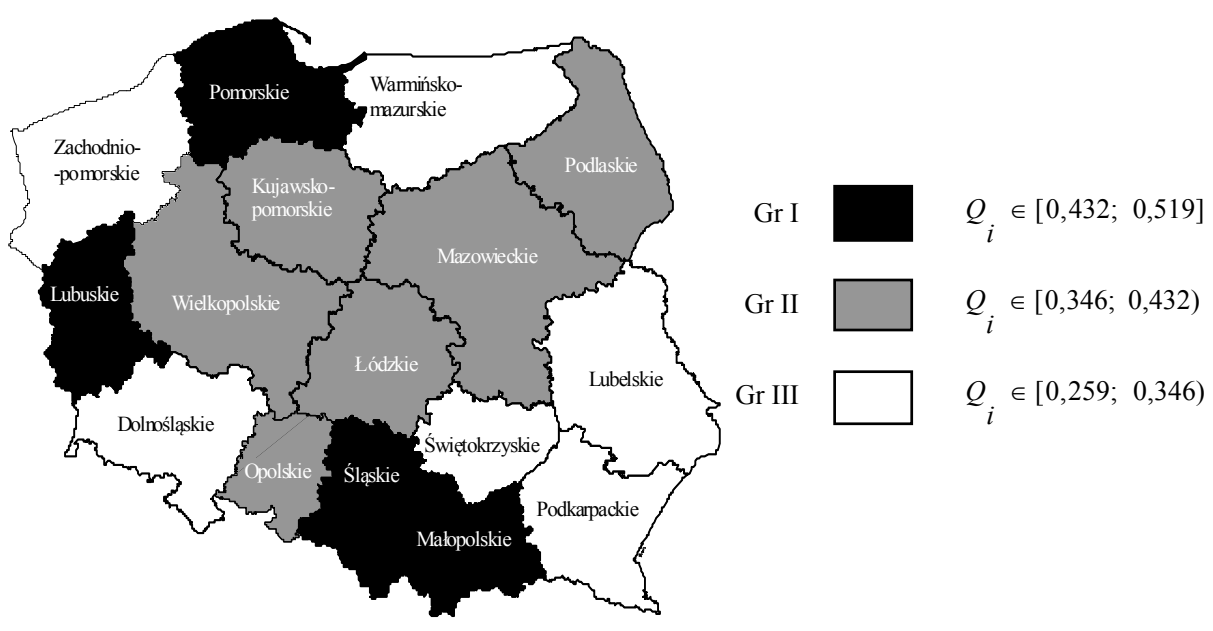

Rys. 3. Województwa podzielone na grupy względem poziomu działalności proekologicznej w 2015 roku.

Fig. 3. Voivodships divided into groups according to the level of pro-ecological activities in 2015

Źródło: Kukuła K. (2017) Pro-Ecological Activity in Poland in 2015 (Regional Study), Acta Scientiarum Polonorum - Oeconomia - w druku. 


\section{Wyniki badań porównawczych w zakresie podobieństwa rankingów}

Rozpatrywane są trzy układy porządkowe województw:

$\mathrm{R}_{1}$ - ranking zanieczyszczenia środowiska, $\mathrm{R}_{2}$ - ranking ponoszonych nakładów na środki trwałe sprzyjające środowisku i $\mathrm{R}_{3}$ - ranking działalności proekologicznej. Analiza komparatywna $\mathrm{w}$ zakresie podobieństwa tych układów pozwala uzyskać odpowiedź na następujące pytanie. W jakim stopniu województwa zanieczyszczające środowisko podejmują czynności naprawcze w formie działań proekologicznych? Uważa się, że podejmowanie działań naprawczych powinno być adekwatne do wyrządzanych szkód. Badania komparatywne $\mathrm{z}$ wykorzystaniem omówionej wcześniej metody porównań międzyrankingowych umożliwią zajęcie stanowiska w omawianej kwestii. Tabela 4 zawiera pozycje (lokaty), jakie dane województwo zajmuje w każdym z trzech omawianych rankingów.

Wykorzystując wyniki obliczeń zamieszczone w tab.4 i stosując wzór (4), otrzymano wartości miar podobieństwa rankingów $\mathrm{R}_{1}$ i $\mathrm{R}_{2} \mathrm{i} \mathrm{R}_{3}$. Ich wyniki zapisano parami w postaci macierzy (7):

$M=\left[m_{p q}\right]=\left[\begin{array}{ccc}1 & 0,586 & 0,383 \\ & 1 & 0,531 \\ & & 1\end{array}\right],(p, q=1,2,3)$

Tabela 4. Pozycje rankingowe województw w trzech kolejno przedstawionych układach porządkowych: $R_{1}, R_{2}$ i $R_{3}$ Table 4. Ranking positions of voivodeships in three subsequently presented linear arrangements: $R_{1}, R_{2}$ and $R_{3}$

\begin{tabular}{|c|c|c|c|c|c|c|c|}
\hline Lp & Województwo & \multicolumn{3}{|c|}{$\begin{array}{c}\text { rangi województw w rankingach } \\
\mathrm{R}_{1} \quad \mathrm{R}_{2} \quad \mathrm{R}_{3}\end{array}$} & \multicolumn{3}{|c|}{$\left|C_{i 1}-C_{i 2}\right| C_{i 1}-C_{i 3} \mid C_{i 2}-C_{i 3}$} \\
\hline 1 & dolnośląskie & 2 & 6 & 11 & 4 & 9 & 5 \\
\hline 2 & kujawsko-pomorskie & 8 & 8 & 10 & 0 & 2 & 2 \\
\hline 3 & lubelskie & 11 & 3 & 15 & 8 & 4 & 12 \\
\hline 4 & lubuskie & 15 & 13 & 3 & 2 & 12 & 10 \\
\hline 5 & łódzkie & 5 & 9 & 6 & 4 & 1 & 3 \\
\hline 6 & małopolskie & 6 & 2 & 1 & 4 & 5 & 1 \\
\hline 7 & mazowieckie & 9 & 5 & 5 & 4 & 4 & 0 \\
\hline 8 & opolskie & 3 & 10 & 9 & 7 & 6 & 1 \\
\hline 9 & podkarpackie & 14 & 14 & 13 & 0 & 1 & 1 \\
\hline 10 & podlaskie & 13 & 15 & 8 & 2 & 5 & 7 \\
\hline 11 & pomorskie & 12 & 7 & 4 & 5 & 8 & 3 \\
\hline 12 & śląskie & 1 & 1 & 2 & 0 & 1 & 1 \\
\hline 13 & świętokrzyskie & 3 & 11 & 14 & 8 & 11 & 3 \\
\hline 14 & warmińsko-mazurskie & 16 & 16 & 12 & 0 & 4 & 4 \\
\hline 15 & wielkopolskie & 7 & 4 & 7 & 3 & 0 & 3 \\
\hline 16 & zachodniopomorskie & 10 & 12 & 16 & 2 & 6 & 4 \\
\hline & & & & & 53 & 79 & 60 \\
\hline
\end{tabular}

Źródło: opracowanie własne na podstawie danych zawartych w tab. 1, 2 i 3.

Informacje zawarte w macierzy podobieństwa badanych układów porządkowych, wskazują, iż tylko rankingi $\mathrm{R}_{1 \mathrm{i}} \mathrm{R}_{2}$ oraz $\mathrm{R}_{2} \mathrm{i} \mathrm{R}_{3}$ wykazują umiarkowany stopień podobieństwa. Niski stopień podobieństwa charakteryzuje rankingi $R_{1} i R_{3}$, co odgrywa $w$ sferze 
interpretacyjnej kluczową rolę. Oczekiwania co do tego, że województwa zanieczyszczające środowisko będą $\mathrm{w}$ proporcjonalnym stopniu podejmować działania o charakterze proekologicznym, niestety nie znalazło potwierdzenia w świetle uzyskanych wyników badań. Umiarkowany (tu najwyższy stopień podobieństwa) cechuje ranking zanieczyszczeń $\mathrm{z}$ rankingiem ponoszonych nakładów na środki trwałe sprzyjające środowisku $\left(m_{12} \equiv 0,596\right)$. Równie umiarkowany aczkolwiek nieco niższy stopień podobieństwa dotyczy rankingów: działalność proekologiczna oraz ponoszone nakłady na wzmiankowane środki trwałe $-\left(\mathrm{m}_{23}=0,531\right)$. Należy podkreślić, że otrzymane wartości miar podobieństwa rankingów określono mianem umiarkowanych podobieństw, gdyż ich wartości znacznie jednak odbiegają od jedności ( $\mathrm{tj}$ stanu idealnego podobieństwa), niewiele przekraczając wartość 0,5 .

Uzyskane wyniki świadczą o tym, że działalność proekologiczna nie nadąża za działaniami niszczącymi środowisko.

\section{Konkluzje}

Na podstawie przeprowadzonych badań oraz własnych spostrzeżeń nasuwa się kilka wniosków.

1. Prezentowane metody podziału obiektów (województw) na grupy o zbliżonych wartościach zmiennej syntetycznej oraz porównań międzyrankingowych charakteryzuje prostota konstrukcji oraz duże możliwości aplikacyjne w kwantytatywnych analizach regionalnych.

2. Pierwszy układ porządkowy tj. ranking $R_{1}$ dotyczący województw sklasyfikowanych ze względu na stopień zanieczyszczenia środowiska wykazuje relatywnie duże zróżnicowanie obiektów w zakresie zmiennej syntetycznej $\left[I\left(Q_{i}\right) \cong 8.6\right]$. Oznacza to, że obiekt pierwszy na liście największych trucicieli środowiska (woj. ślaskie) przewyższa prawie dziewięciokrotnie woj. warmińsko-mazurskie (stosunkowo mało skażone), zajmujące ostatnią lokatę na wspomnianej liście.

3. Największe wewnętrzne zróżnicowanie charakteryzuje ranking $R_{2}$ tj. układ porządkowy województw ze względu na wysokość nakładów ponoszonych na środki trwałe sprzyjające środowisku $\left[I\left(Q_{i}\right) \cong 14\right]$.

4. Najsłabsze zróżnicowanie obiektów pod względem wartości zmiennej syntetycznej odnotowano w rankingu $\mathrm{R}_{3} \mathrm{tj}$ w układzie porządkowym województw ze względu na poziom działalności proekologicznej $\left[I\left(Q_{i}\right) \cong 2\right]$. Wynik ten należy ocenić negatywnie w zestawieniu z rezultatami dotyczącymi rankingów $R_{1} i R_{2 .}$. Otrzymany wynik pozwala stwierdzić, że działalność proekologiczna w poszczególnych województwach nie jest realizowana w sposób proporcjonalny do wyrządzanych szkód środowisku. Wyjątek stanowi województwo śląskie, które podejmuje działanie naprawcze adekwatne do emitowanych zanieczyszczeń

5. Dysproporcje w układach rankingowych ujawnione za pomocą ilorazu wartości skrajnych zmiennej syntetycznej potwierdzają niektóre spostrzeżenia. Przykładowo, takie województwa, jak: dolnośląskie, opolskie i świętokrzyskie zajmują odpowiednio 2,3 i 4 lokatę w rankingu największych trucicieli środowiska, (grupa I w rankingu $\mathrm{R}_{1}$ ), te same 


\section{K. Kukuła}

województwa w rankingu $\mathrm{R}_{3}$ - poziom działań proekologicznych- zajmują odpowiednio 11 , 9 i 14 lokatę, przynależąc do grup III i II.

6. Dotychczas poczynione spostrzeżenia potwierdzają wyniki porównań międzyrankingowych. Niższy relatywnie stopień zgodności między rankingami $R_{1}$ i $R_{3}$ $\left(\mathrm{m}_{13}=0,383\right)$ sugeruje, iż województwa działające wyraźnie na szkodę środowiska nie podejmują w odpowiedniej skali czynności zmierzających do jego ochrony.

7. W Polsce daje się zauważyć wciąż rosnącą świadomość społeczną o konieczności ochrony środowiska, niestety nie idą za tym konkretne działania proekologiczne adekwatnie do potrzeb w tym zakresie.

\section{Literatura}

Dobrzański, G. (red.) (2009). Ochrona środowiska przyrodniczego, Wydawnictwo Naukowe PWN, Warszawa.

Grabiński, T. (1984). Wielowymiarowa analiza porównawcza w badaniach dynamiki zjawisk ekonomicznych Zeszyty Naukowe AE, Seria specjalna: Monografie, Kraków.

Hellwig, Z. (1968). Zastosowanie metody taksonomicznej do typologicznego podziału krajów ze względu na poziom ich rozwoju oraz zasoby i strukturę wykwalifikowanych kadr. Przegląd Statystyczny, 4, 307-326.

Jajuga, K. (1993) Statystyczna analiza wielowymiarowa, $P W N$, Warszawa.

Kukuła, K. (1986). Propozycja miary zgodności układów porządkowych. Zeszyty Naukowe AE, Kraków 22, 81-104.

Kukuła, K. (2000). Metoda unitaryzacji zerowanej, Wydawnictwo Naukowe PWN, Warszawa.

Kukuła, K. (2014). Wybrane problemy ochrony środowiska w Polsce w świetle wielowymiarowej analizy porównawczej. Metody Ilościowe w Badaniach Ekonomicznych, 15(3), 169-188.

Kukuła, K., Luty, L. (2015). Propozycja procedury wspomagającej wybór metody porządkowania liniowego. Przeglad Statystyczny, 62(2), 219-231.

Kukuła, K. (2017). Pro-Ecological Activity in Poland in 2015 (Regional Study). Acta Scientiarum Polonoruum Oeconomia, w druku

Młodak, A. (2006). Analiza taksonomiczna w statystyce regionalnej, Difin, Warszawa

Panek, T. (2009). Statystyczne metody wielowymiarowej analizy porównawczej, SGH, Oficyna Wydawnicza Warszawa.

Pluta, W. (1977). Wielowymiarowa analiza porównawcza w badaniach ekonomicznych, $P W E$, Warszawa.

Poskrobko, B. (1987). Podstawy użytkowania i ochrony środowiska, Wydawnictwo Politechniki Białostockiej, Białystok.

Strahl, D. (1978). Propozycja konstrukcji miary syntetycznej. Przeglą Statystyczny, 2, 205-215.

Walesiak, M. (2014). Przeglą formuł normalizacji wartości zmiennych oraz ich własności w statystycznej analizie wielowymiarowej. Przegląd Statystyczny, 4, 363-372. 